\title{
PENGARUH STRATEGI PEMBELAJARAN DAN MINAT KEJURUAN TERHADAP HASIL BELAJAR MENGUASAI DASAR INSTALASI LISTRIK PESERTA DIDIK PROGRAM KEAHLIAN TEKNIK PEMANFAATAN TENAGA LISTRIK SMK NEGERI 5 MEDAN
}

\author{
Siagian Binahar ${ }^{1}$, Julaga Situmorang ${ }^{2}$ \\ Pascasarjana Universitas Negeri Medan ${ }^{1,2}$ \\ siagianbinahar@yahoo.com ${ }^{l}$
}

\begin{abstract}
Abstrak: Penelitian ini bertujuan untuk mengetahui: (1) hasil belajar Dasar Instalasi Listrik peserta didik yang diajar dengan strategi pembelajaran kontekstual lebih tinggi dibandingkan dengan peserta didik yang diajar dengan strategi pembelajaran ekspositori, (2) hasil belajar Dasar Instalasi Listrik peserta didik yang memiliki minat kejuruan tinggi lebih tinggi dibandingkan dengan peserta didik yang memiliki minat kejuruan rendah dan (3) interaksi antara strategi pembelajaran dengan minat kejuruan dalam mempengaruhi hasil belajar Dasar Instalasi Listrik peserta didik. Metode penelitian quasi eksperimen dengan desain faktorial $2 \times 2$. Teknik analisis yang digunakan adalah analisis varians dua jalur (Two Way Anava $2 \times 2$ ) dengan taraf signifikansi $\alpha=0,05$ dengan menggunakan Uji-F, pengujian uji lanjut menggunakan uji Scheffe. Temuan penelitian menunjukkan: (1) hasil belajar Dasar Instalasi Listrik peserta didik yang diajar dengan strategi pembelajaran kontekstual lebih tinggi dibandingkan dengan hasil belajar peserta didik yang diajar dengan strategi pembelajaran ekspositori, (2) hasil belajar Dasar Instalasi Listrik peserta didik yang memiliki minat kejuruan tinggi lebih tinggi dibandingkan dengan hasil belajar peserta didik yang memiliki minat kejuruan rendah. dan (3) terdapat interaksi antara strategi pembelajaran dengan minat kejuruan dalam mempengaruhi hasil belajar Dasar Instalasi Listrik peserta didik.
\end{abstract}

Kata kunci: strategi pembelajaran, minat kejuruan, menguasai dasar instalasi listrik, program keahlian teknik pemanfaatan tenaga listrik

\begin{abstract}
This study aims to determine: (1) the learning outcomes Basic Electrical Installation learners taught by contextual learning strategy was higher than students taught by instructional strategies expository, (2) the learning outcomes Basic Electrical Installations students who have an interest high vocational higher compared with students who have a lower vocational interests and (3) the interaction between the learning strategy with a vocational interest in affecting learning outcomes Basic Electrical Installation learners. The research method quasi with $2 \times 2$ factorial design analysis technique used is the analysis of variance of two lanes (Two Way Anova $2 \times 2$ ) with significance level $\alpha=0.05$ using the Test-F, testing a further test using Scheffe test. The findings show: (1) the learning outcomes Basic Electrical Installation learners taught by contextual learning strategies more than in the learning outcomes of students taught by instructional strategies expository, (2) the learning outcomes Basic Electrical Installations students who have interest in vocational high higher than the learning outcomes of students who have a vocational interest low. and (3) there is interaction between the learning strategy with a vocational interest in affecting learning outcomes Basic Electrical Installation learners.
\end{abstract}

Keywords: learning strategies, vocational interests, mastering basic electrical installation, program utilization of electric power engineering

\section{PENDAHULUAN}

Sekolah Menengah Kejuruan (SMK) merupakan salah satu lembaga pendidikan yang bertujuan untuk mempersiapkan lulusannya menjadi tenaga kerja yang mempunyai pengetahuan dan keterampilan tingkat menengah sesuai dengan bidangnya. Hal ini sesuai dengan pasal 11 ayat 3 UU Nomor 2 Tahun !989 tentang pendidikan nasional yang menyebutkan bahwa pendidikan kejuruan merupakan pendidikan yang mempersiapkan peserta didik untuk dapat bekerja pada bidang 
tertentu.. Untuk mencapai tujuan tersebut pembinaan peserta didik yang akan terjun ke masyarakat harus dilakukan seoptimal mungkin, baik mengenai kompetensi kejuruan maupun bidang disiplin ilmu. Hal ini sesuai dengan tujuan SMK dalam GBPP 1999 Nasional yaitu: (1) menyiapkan peserta didik untuk memasuki lapangan kerja serta mengembangkan sikap profesional, (2) menyiapkan peserta didik agar mampu memilih karir, mampu berkompetensi dan mampu mengembangkan diri, (3) menyiapkan tenaga kerja tingkat menengah pada saat ini maupun pada saat mendatang dan (4) menyiapkan tamatan agar mampu menjadi warga negara yang produktif, adaptif dan kreatif.

Menurut Sanjaya (2005: 109) bahwa pembelajaran kontekstual adalah konsep yang membantu guru mengkaitkan antara materi pembelajaran dengan dunia nyata peserta didik, dan mendorong peserta didik membuat hubungan antara pengetahuan yang dimilikinya dengan penerapannya dalam kehidupan seharihari. Pengetahuan dan keterampilan peserta didik diperoleh dari usaha peserta didik mengkontruksi sendiri pengetahuan dan keterampilan baru ketika ia belajar. (Nurhadi, 2003: 5).

Salah satu faktor yang berasal dari dalam diri peserta didik adalah minat kejuruan, yang diprediksi akan menentukan keefektifan strategi pembelajaran.

Menurut Uzer (1997: 27) bahwa kondisi belajar mengajar yang efektif adalah adanya minat dan perhatian peserta didik dalam belajar dimana minat merupakan suatu sifat yang menetap pada diri seseorang.

Selanjutnya Richard Dewey dan WJ Humber dalam Rakhmat (1996: 43 ) menyebutkan bahwa minat adalah keinginan untuk mencapai tujuan tertentu yang begitu kuat sehingga mendorong anak untuk mengorbankan nilai-nilai yang lain, yang tidak sesuai dengan pencapaian tujuan dilandasi pengetahuan serta dipengaruhi oleh kecerdasan dan energi.

Senada dengan hal tersebut di atas Yani (1996: 76) mengungkapkan minat merupakan rasa tertarik sesorang terhadap sesuatu hal sehingga mendorong untuk mengerjakan apa yang diinginkan, memberi arahan untuk bertindak agar memperoleh kepuasan dan kenikmatan. Lebih lanjut Hurluck (1990: 149) mengatakan bahwa minat merupakan sumber motivasi yang mendorong individu untuk melakukan apa yang diinginkan dengan kebebasan memilih. Bila mereka melihat sesuatu yang mempunyai manfaat bagi dirinya, maka mereka akan tertarik dan menimbulkan kepuasan.

Dalam kaitannya dengan kejuruan, Kamisa (1997) menyatakan bahwa kejuruan adalah keahlian dalam suatu bidang tertentu atau keahlian khusus dan keahlian dalam melakukan sesuatu. Lebih lanjut Kamisa (1997) menyatakan bahwa keahlian adalah kemahiran dalam suatu ilmu. Evash (1968) mengemukakan pendidikan kejuruan mencakup semua pendidikan yang membentuk seseorang lebih kompeten dari pada yang lain dalam suatu pekerjaan sehingga peserta didik yang telah memasuki pendidikan kejuruan telah memiliki suatu keahlian yang mengarahkan kepada suatu pekerjaan.

Belajar adalah suatu proses usaha yang dilakukan seseorang untuk emperoleh suatu perubahan tingkah laku yang baru secara keseluruhan, sebagai hasil pengalamannya sendiri dalam interaksi dengan lingkungannya (Slameto 2003: 2). Selanjutnya Skinner seperti dikutip oleh Bigge (1982: 119) berpandangan bahwa belajar adalah proses adaptasi yang berlangsung secara progresif. Skinner percaya bahwa proses belajar akan optimal jika diberi penguatan (reinforcer). Skinner berpendapat bahwa proses belajar muncul akibat hubungan stimulus dan respon. Ketika seseorang belajar, maka responsnya menjadi lebih baik. Sebaliknya bila seseorang tidak belajar maka responsnya menurun (Dimyati, 2006: 9-10).

Secara sederhana Gagne mendefinisikan belajar sebagai hasil dari interaksi antara individu dengan lingkungannya (Gagne \& Driscoll, 1989: 21). Gagne seperti dikutip oleh Bigge (1982: 41) mendefinisikan belajar sebagai perubahan dalam prilaku dan keterampilan manusia yang dapat dipakai, dan bukan dianggap berasal dari proses pertumbuhan. Gagne memandang belajar sebagai proses perubahan prilaku akibat pengalaman yang dialaminya.

Chaplin seperti dikutip oleh Syah (2008: 65) memberikan batasan defenisi belajar yang menyinggung teori belajar Gagne dan Skinner. Chaplin membatasi belajar dengan dua rumusan yaitu: (1) belajar adalah perolehan perubahan tingkah laku yang relatif menetap sebagai akibat latihan dan pengalaman, (2) belajar ialah proses memperoleh respon-respon sebagai akibat adanya latihan khusus. 
Hampir senada dengan Chaplin, Reber seperti dikutip oleh Syah (2008: 66) defenisi belajar dibagi menjadi dua. Pertama, belajar adalah proses memperoleh pengetahuan. Istilah ini sering dipakai dalam pembahasan psikologi kognitif. Kedua, belajar adalah suatu perubahan kemampuan bereaksi yang relatif langgeng sebagai hasil latihan yang diperkuat. Dalam definisi ini terkandung empat istilah penting dalam memahami makna belajar yaitu: (1) relatively permanent (menetap), (2) response potentiality (kemampuan bereaksi), (3) reinforced (yang diperkuat) dan (4) practice (latihan).

Biggs seperti dikutip oleh Syah (2008: 67) mendefinisikan belajar dalam tiga rumusan, yaitu: Rumusan kuantitatif, rumusan institusional dan rumusan kualitatif. Secara kuantitatif belajar adalah kegiatan pengembangan kemampuan kognitif dengan fakta sebanyak-banyaknya. Dalam hal ini, belajar dipandang dari sudut seberapa banyak materi yang dikuasai peserta didik. Secara intitusional belajar dipandang sebagai proses validasi terhadap penguasaan peserta didik atas materi-materi yang telah dipelajari. Ukurannya adalah semakin baik mutu mengajar guru maka semakin baik pula mutu hasil belajar peserta didik. Sedangkan secara kualitatif belajar adalah proses memperoleh arti dan pemahaman serta cara menafsirkan dunia di sekeliling peserta didik. Belajar di sini difokuskan pada tercapainya daya fikir dan tindakan yang berkualitas untuk memecahkan masalah yang dihadapi peserta didik.

Dalam bahasa yang lebih sederhana Fajar (2004: 10) mendefinisikan belajar sebagai suatu proses perubahan dalam diri seseorang yang ditampakkan dalam bentuk peningkatan kualitas dan kuantitas tingkah laku seperti peningkatan pengetahuan, kecakapan, daya pikir, sikap, kebiasaan, dan lain-lain. Dari beberapa pendapat ahli di atas dapat disimpulkan pengertian belajar sebagai suatu proses perubahan tingkah laku baik secara kualitas maupun kuantitas yang dipengaruhi dan diperkuat oleh lingkungan yang bersifat permanen sebagai akibat dari latihan-latihan.

Hasil belajar didefinisikan oleh Romiszwoski (1981: 63) sebagai output (keluaran) dari suatu sistem pemrosesan input (masukan). Input dapat berupa berbagai informasi sedangkan output berupa performance (kinerja). Kinerja memberi petunjuk bahwa proses belajar telah terjadi. Romiszwoski mengkategorikan hasil belajar dalam dua macam yaitu keterampilan dan pengetahuan. Pengetahuan terdiri dari empat kategori. (1) pengetahuan tentang fakta, (2) pengetahuan tentang konsep, (3) pengetahuan tentang prinsip dan (4) pengetahuan tentang prosedur. Fakta merupakan pengetahuan tentang objek yang nyata, yang merupakan asosiasi dari kenyataan-kenyataan dan informasi verbal dari suatu objek, peristiwa atau manusia. Konsep merupakan pengetahuan tentang tindakan demi tindakan yang bersifat linier dalam mencapai suatu tujuan, sedangkan prinsip adalah pernyataan mengenai hubungan dua konsep atau lebih, hubungan itu bersifat kausalitas, korelasi atau aksiomatis.

Keterampilan dikelompokkan ke dalam empat kategori. (1) keterampilan kognitif, (2) aksi, (3) reaksi dan (4) interaksi. Keterampilan kognitif berkaitan dengan keterampilan seseorang menggunakan pikiran dalam menghadapi sesuatu, seperti mengambil keputusan atau memecahkan masalah. Keterampilan melakukan aksi berkaitan dengan keterampilan fisik seperti berolahraga, teknik dan lain-lain. Keterampilan bereaksi adalah keterampilan seseorang berhubungan dengan sesuatu situasi dalam artian nilai-nilai emosi dan perasaan. Keterampilan interaktif adalah keterampilan seseorang berhubungan dengan orang lain untuk mencapai suatu tujuan seperti komunikasi, persuasi dan pendidikan.

Hasil belajar merupakan hasil dari suatu interaksi tindak belajar dan tindak mengajar (Dimyati, 2006: 3). Hasil interaksi ini menyebabkan perubahan tingkah laku yang dapat diamati pada penampilan orang tersebut. Penampilan yang merupakan bukti proses belajar melalui program-program pendidikan yang beraneka ragam dari yang sederhana sampai yang paling kompleks.

Perubahan yang terjadi dalam proses belajar adalah berkat pengalaman atau praktek yang dilakukan dengan sengaja dan disadari dengan kata lain bukan karena kebetulan. Dalam diri peserta didik terjadi perubahan seperti penambahan pengetahuan, sikap, dan keterampilan.Di samping itu peserta didik juga diarahkan pada tercapainya perubahan tersebut.

Gagne (Gagne and Driscoll, 1989: 44) membagi hasil belajar dalam lima tipe. (1) informasi verbal, pengetahuan verbal ini disimpan sebagai jaringan proposisi-proposisi. Informasi verbal diperoleh dari kegiatan 
pembelajaran di sekolah, buku, radio, TV, percakapan orang lain dan lain-lain, (2) keterampilan intelektual, memungkinkan seseorang berinteraksi dengan lingkungannya melalui penggunaan simbol atau gagasan, (3) strategi kognitif, merupakan proses kontrol, yaitu proses internal yang digunakan peserta didik untuk memilih atau mengubah cara-cara memberikan perhatian, belajar, mengingat dan berfikir, (4) sikap merupakan pembawaan yang dapat dipelajari, dan dapat mempengaruhi prilaku seseorang terhadap lingkungannya dan (5) keterampilan motorik yaitu keterampilan yang tidak hanya mencakup kegiatan fisik, melainkan juga kegiatan-kegiatan motorik yang digabung dengan keterampilan intelektual.

Dasar Instalasi Listrik merupakan salah satu mata pelajaran dalam program produktif yang harus dikuasai oleh peserta didik SMK program keahlian Teknik Pemanfaatan Tenaga Listrik. Dasar Instalasi Listrik memiliki waktu 64 jam pelajaran yang diberikan pada semester I dan II. Dasar Instalasi Listrik meliputi beberapa sub kompetensi dasar yaitu: (1) dasar instalasi listrik sederhana sesuai dengan peraturan dan keselamatan kerja dan (2) memasang instalasi sederhana. Jadi hasil belajar Dasar Instalasi Listrik adalah bentuk penguasaan dalam wujud perilaku kognitif yang diperoleh akibat adanya suatu proses pembelajaran. Hasil belajar yang diperoleh peserta didik melalui proses pembelajaran dapat diketahui melalui evaluasi hasil belajar yang dapat dilakukan melalui seperangkat test yang disusun sesuai dengan materi pelajaran yang diberikan. Hasil belajar ini menggambarkan tingkat keberhasilan peserta didik dalam proses pembelajaran yang dilaksanakan.

Strategi pembelajaran berhubungan dengan cara menyampaikan pesan dalam pembelajaran. Strategi pembelajaran meliputi sifat, ruang lingkup, dan rangkaian kejadian yang mengandung pengalaman belajar. Strategi pembelajaran harus memperhitungkan tujuan pembelajaran yang telah ditetapkan dan mempertimbangkan karakteristik peserta didik. Strategi pembelajaran adalah rencana untuk mencapai tujuan pembelajaran yang dikembangkan dari metode-metode dan teknikteknik yang akan membantu peserta didik mencapai tujuan pembelajarannya (Gerlach \& Ely 1980: 174).

Untuk mencapai tujuan pembelajaran, diperlukan strategi pembelajaran yang sesuai dengan tujuan pembelajaran tersebut. Dick, W
\& Carey, L (2005: 37) mengemukakan bahwa strategi pembelajaran merupakan komponenkomponen umum dari suatu set bahan pembelajaran dan prosedur-prosedur yang akan digunakan untuk menghasilkan hasil belajar tertentu pada peserta didik.

Strategi pembelajaran berkenaan dengan pendekatan pembelajaran dalam mengelola kegiatan pembelajaran untuk menyampaikan materi secara sistematis sehingga kemampuan yang diharapkan dapat dikuasai oleh peserta didik secara efektif dan efisien. Menurut Miarso (2007: 530) strategi pembelajaran merupakan pendekatan menyeluruh pembelajaran dalam suatu sitem pembelajaran, yang berupa pedoman umum dan kerangka kegiatan untuk mencapai tujuan umum pembelajaran, yang dijabarkan dari pandangan falsafah atau teori belajar tertentu.

David seperti dikutip oleh Sanjaya (2008: 126) mendefinisikan strategi pembelajaran sebagai perencanaan yang berisi tentang rangkaian kegiatan yang didesain untuk mencapai tujuan pendidikan tertentu. Sedangkan menurut Kirby (1984: 5) strategi sesungguhnya, merupakan metode untuk menyelesaikan tugas-tugas, atau secara umum untuk mencapai tujuan. Strategi pembelajaran adalah metode untuk mencapai tujuan pembelajaran.

Prawiradilag

(2008:

mendefinisikan strategi pembelajaran sebagai upaya yang dilakukan oleh perancang dalam menentukan teknik penyampaian pesan, penentuan metode dan media, alur isi pelajaran serta interaksi antara pengajar dan peserta didik.

Terdapat prinsip-prinsip umum penggunaan strategi pembelajaran (Sanjaya, 2008: 131) yaitu: (1) berorientasi pada tujuan, yaitu dalam pembelajaran tujuan merupakan komponen yang utama, keberhasilan suatu strategi tergantung pada tercapainya tujuan, (2) aktivitas, strategi pembelajaran harus dapat mendorong aktivitas peserta didik, (3) individualitas, strategi pembelajaran pada hakikatnya ingin mencapai perubahan prilaku setiap peserta didik dan (4) integritas, strategi pembelajaran harus dapat mengembangkan seluruh aspek kepribadian peserta didik secara terintegrasi.

Dalam pembelajaran kontekstual tugas guru adalah memberikan kemudahan belajar bagi peserta didik, dengan menyediakan berbagai sarana dan sumber belajar yang memadai. Guru bukan hanya menyampaikan 
materi pembelajaran yang berupa hafalan tetapi mengatur lingkungan dan strtegi pembelajaran yang memungkinkan peserta didik belajar dengan baik. Lingkungan belajar yang kondusif sangat penting dalam menunjang pembelajaran kontekstual, dan keberhasilan proses pembelajaran secara keseluruhan. Nurhadi (2003: 18) mengemukakan pentingnya lingkungan belajar dalam pembelajaran kontekstual sebagai berikut: (1) belajar efektif itu dimulai dari lingkungan belajar yang berpusat pada peserta didik, (2) pembelajaran harus berpusat kepada bagaimana cara peserta didik menggunakan pengetahuan baru. Strategi belajar lebih dipentingkan dari pada hasilnya, (3) umpan balik amat penting bagi peserta didik, yang berasal dari proses penilaian yang benar dan (4) menumbuhkan komunitas belajar dalam bentuk kelompok itu penting.

Dalam pembelajaran kontekstual guru harus dapat memilih dan mendesain lingkungan belajar yang memungkinkan untuk mengaitkan pengetahuan lama dengan pengetahuan baru peserta didik. Zahorik (M. Masnur, 2007: 52) menyatakan ada lima elemen yang harus diperhatikan dalam pembelajaran kontekstual, sebagai berikut: (1) mengaktifan pengetahuan yang sudah ada, (2) pemerolehan pengetahuan baru dengan cara mempelajari secara keseluruhan dulu, kemudian memperhatikan detailnya, (3) pemahaman pengetahuan, yaitu dengan cara menyusun konsep sementara, melakukan sharing kepada orang lain untuk memperoleh masukan dan tanggapan dari orang lain, merevisi dan mengembangkan konsep, (4) mempraktikkan pengetahuan dan pengalaman dan (5) melakukan refleksi terhadap strategi pengembangan pengetahuan.

Strategi pembelajaran ekspositori merupakan strategi memberitahukan atau menjelaskan (Jarolimek \& Foster, 1976: 94). Dalam strategi pembelajaran ekspositori guru menjadi sumber informasi utama, namun sumber data dan infromasi lain juga dapat digunakan. Sumber informasi yang paling sering dipakai adalah buku teks. Sumber lain seperti gambar, filmstrip, ensiklopedi, perpustakaan juga sering digunakan dalam strategi pembelajaran ekspositori.

Strategi pembelajaran ekspositori menurut Sanjaya (2009: 179) adalah strategi pembelajaran yang menekankan pada proses penyampaian materi secara verbal dari seorang guru kepada sekelompok peserta didik dengan maksud agar peserta didik dapat menguasai materi pelajaran secara optimal.

Strategi pembelajaran ekspositori sering dihubungkan dengan kurangnya latihan dalam pembelajaran, menggunakan buku secara monoton, kekakuan, penekanan pada pembelajaran berdasarkan fakta dan hafalan, menggunakan metode ceramah, dan lain-lain. Manson dan Williams menjelaskan seperti yang dikutip oleh Jarolimek \& Foster (1976: 95), pembelajaran yang berbasis pada peserta didik secara umum diajukan sebagai antitesis strategi pembelajaran ekspositori di mana pembelajar menjadi penerima pengetahuan. Strategi pembelajaran ekpositori lebih cocok digunakan untuk mentransfer pengetahuan.

Terdapat beberapa karakteristik pada strategi pembelajaran ekspositori (Sanjaya, 2008: 179) yaitu seperti berikut ini: (1) strategi ekspositori dilakukan dengan cara menyampaikan materi pelajaran secara verbal, artinya bertutur lisan merupakan alat utama dalam melakukan strategi ini, oleh karena itu orang sering mengidentikkannya dengan ceramah, (2) biasanya materi pelajaran yang disampaikan adalah materi pelajaran yang sudah jadi, seperti data atau fakta, konsepkonsep tertentu yang sudah dihafal sehingga tidak menuntut peserta didik untuk berfikir ulang, (3) tujuan utama pembelajaran adalah penguasaan materi pelajaran itu sendiri. Artinya, setelah proses pembelajaran berakhir peserta didik diharapkan dapat memahaminya dengan benar dengan cara dapat menggungkapkan kembali materi yang telah diuraikan.

Keberhasilan pendidikan seperti yang telah dicita-citakan oleh setiap lembaga pendidikan ditentukan oleh banyak faktor seperti: minat, sikap, bakat, waktu, lingkungan belajar, kondisi ekonomi dan lain sebagainya. Demikian halnya dengan keberhasilan suatu mata pelajaran tertentu, misalnya pada mata pelajaran di SMK juga ditentukan oleh berbagai faktor diatas. Menurut Uzer (1997: 27) bahwa kondisi belajar mengajar yang efektif adalah adanya minat dan perhatian peserta didik dalam belajar dimana minat merupakan suatu sifat yang menetap pada diri seseorang.

Chaplin (1995: 255) menyebutkan minat dengan interest, mengartikan minat sebagai sebuah sikap yang berlangsung terus menerus yang menolakkan perhatian seseorang, sehingga membuat dirinya menjadi selekti terhadap objek minatnya. Selanjutnya Richard 
Dewey dan WJ Humber dalam Rakhmat (1996: 43 ) menyebutkan bahwa minat adalah keinginan untuk mencapai tujuan tertentu yang begitu kuat sehingga mendorong anak untuk mengorbankan nilai-nilai yang lain, yang tidak sesuai dengan pencapaian tujuan dilandasi pengetahuan serta dipengaruhi oleh kecerdasan dan energi.

Senada dengan hal tersebut di atas Yani (1996: 76) mengungkapkan minat merupakan rasa tertarik sesorang terhadap sesuatu hal sehingga mendorong untuk mengerjakan apa yang diinginkan, memberi arahan untuk bertindak agar memperoleh kepuasan dan kenikmatan. Sementara itu Walgito (1986: 38) mengatakan bahwa minat adalah suatu keadaan di mana seseorang mempunyai perhatian terhadap objek tersebut disertai dengan keinginan-keinginan untuk mengetahui dan mempelajari maupun membuktikan lebih lanjut kecenderungan untuk berhubungan lebih aktif terhadap objek tersebut.

Rumuskan masalah sebagai berikut: (1) Apakah hasil belajar Dasar Instalasi Listrik peserta didik yang diajar dengan strategi pembelajaran kontekstual lebih tinggi dibandingkan peserta didik yang diajar dengan strategi pembelajaran ekspositori?; (2) Apakah hasil belajar Dasar Instalasi Listrik peserta didik yang memiliki minat kejuruan tinggi lebih tinggi dibandingkan peserta didik yang memiliki minat kejuruan rendah?; (3) Apakah terdapat interaksi antara strategi pembelajaran dengan minat kejuruan dalam mempengaruhi hasil belajar Dasar Instalasi Listrik peserta didik?

\section{METODE}

Penelitian ini dilaksanakan di SMK Negeri 5 Medan pada kelas X Program Keahlian TPTL. Penelitian ini dilaksanakan dalam rentang waktu delapan kali pertemuan.
Populasi penelitian ini adalah seluruh peserta didik kelas X Program Keahlian TPTL SMK Negeri 5 Medan, yang terdiri dari 3 (tiga) kelas dengan jumlah seluruh peserta didik 120 orang.

Setiap kelas memiliki karakteristik yang sama, artinya setiap kelas tidak memiliki peserta didik yang pernah tinggal kelas, peserta didik rata-rata memiliki umur yang tidak jauh berbeda dan menggunakan kurikulum yang sama. Pembagian kelas tidak dilakukan berdasarkan rangking, sehingga tidak terdapat kelas unggulan yang karakteristiknya peserta didiknya berbeda.

Teknik pengambilan sampel yang digunakan adalah teknik pengambilan sampel kelompok secara acak (cluster random sampling), yakni semua individu dalam kelas sampel menjadi subjek penelitian. Dengan menggunakan teknik sampling di atas terpilih kelas $\mathrm{X}_{\text {TPTL1 }}$ sebagai kelas eksperimen (kelas yang diberi perlakuan dengan strategi pembelajaran kontekstual) dengan jumlah 40 orang dan kelas X TPTL2 sebagai kelas kontrol (kelas yang diberi perlakuan dengan strategi ekspositori) dengan jumlah 40 orang.

Penelitian ini menggunakan metode eksperimen dengan rancangan quasi eksperimen disain faktorial $2 \times 2$. Melalui disain ini akan dibandingkan pengaruh strategi pembelajaran kontekstual dan strategi pembelajaran ekspositori. Strategi pembelajaran kontekstual dan strategi pembelajaran ekspositori diperlakukan kepada kelompok eksperimen peserta didik dengan minat kejuruan yang berbeda. Strategi pembelajaran kontekstual dan strategi pembelajaran ekspositori sebagai variabel bebas. Minat kejuruan tinggi dan minat kejuruan rendah sebagai variabel moderator dan hasil belajar Dasar Instalasi Listrik sebagai variabel terikat. Variabel-variabel tersebut selanjutnya akan ditinjau dalam penelitian dengan disain ditunjukkan dalam Tabel 1.

Tabel 1. Desain Eksperimen Faktorial 2x2

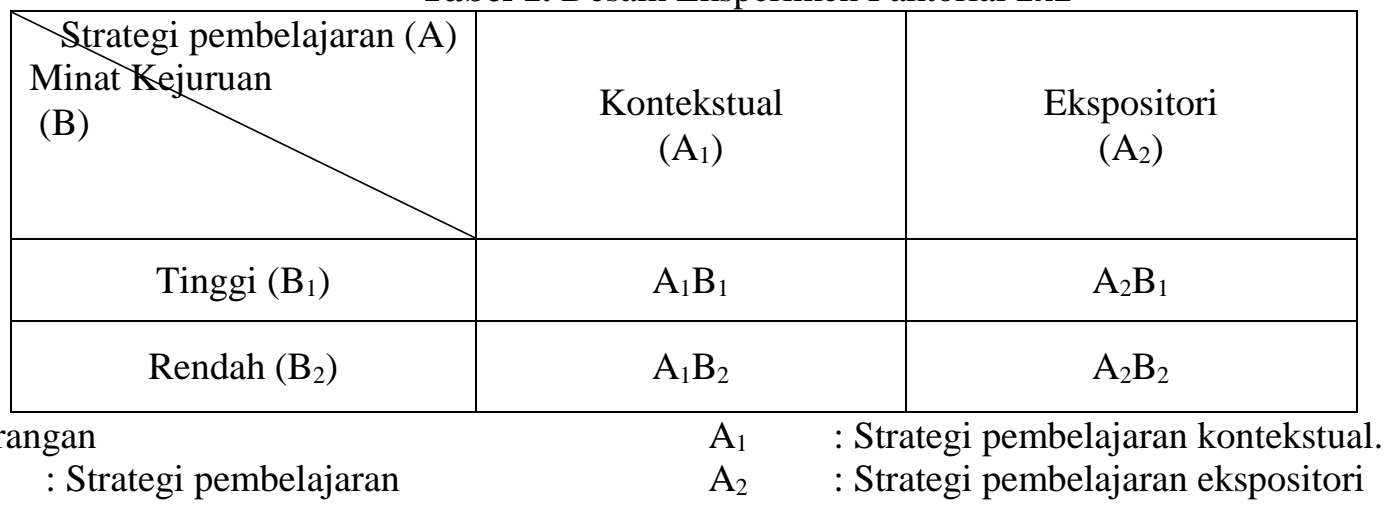


B : Minat kejuruan

$\mathrm{B}_{1} \quad$ : Minat kejuruan tinggi

$\mathrm{B}_{2} \quad$ : Minat kejuruan rendah

$\mathrm{A}_{1} \mathrm{~B}_{1}$ : Dasar Instalasi Listrik peserta didik yang yang diajar dengan strategi pembelajaran kontekstual dan memiliki minat kejuruan tinggi.

$\mathrm{A}_{1} \mathrm{~B}_{2} \quad$ : Hasil belajar Dasar Instalasi Listrik peserta didik yang diajar dengan strategi pembelajaran kontekstual dan memiliki minat kejuruan rendah.

$\mathrm{A}_{2} \mathrm{~B}_{1} \quad$ : Hasil belajar Dasar Instalasi Listrik peserta didik yang diajar dengan strategi pembelajaran ekspositori dan memiliki minat kejuruan tinggi.

$\mathrm{A}_{2} \mathrm{~B}_{2}$ : : Hasil belajar Dasar Instalasi Listrik peserta didik yang diajar dengan strategi pembelajaran ekspositori dan memiliki minat kejuruan rendah.

Teknik analisis data yang digunakan adalah Teknik Statistik Deskriptif dan Inferensial. Teknik statistik deskriptif digunakan untuk mendeskripsikan data, antara lain: nilai mean, median, modus, standard deviasi dan kecenderungan data. Teknik statistik Inferensial digunakan untuk menguji hipotesis penelitian, di mana teknik Inferensial yang akan digunakan adalah teknik Analisis Varians (ANAVA) dua jalur (disain faktorial $2 \times 2$ ) dengan taraf signifikan 5\%. Sebelum ANAVA dua jalur dilakukan, terlebih dahulu dilakukan uji persyaratan analisis yakni uji persyaratan normalitas menggunakan Uji Lilliefors, sedangkan untuk uji persyaratan homogenitas menggunakan Uji Fisher dan Uji Bartlett (Sudjana, 2005: 261).

Setelah melakukan pengujian persyaratan analisis, selanjutnya dilakukan

pengujian Anava 2 jalur. Uji lanjut dilakukan dengan Uji Scheffe karena jumlah sampel tiap sel tidak sama (n tidak sama).

Berdasarkan hipotesis penelitian yang telah dirumuskan di muka, maka berikut ini dapat disusun hipotesis statistik yang akan diuji sebagai berikut:

1. Hipotesis Pertama: Ho $: \mu_{\mathrm{A} 1}=\mu_{\mathrm{A} 2}$

$\mathrm{Ha}: \mu_{\mathrm{A} 1}>\mu_{\mathrm{A} 2}$

2. Hipotesis Kedua: Ho $: \mu_{\mathrm{B} 1}=\mu_{\mathrm{B} 2}$

$\mathrm{Ha}: \mu_{\mathrm{B} 1}>\mu_{\mathrm{B} 2}$

3. Hipotesis Ketiga: Ho : $\mathrm{A} \times \mathrm{B}=0$

$\mathrm{Ha}: \mathrm{A} \times \mathrm{B} \neq 0$

Keterangan:

$\mu_{A I}=$ Rata-rata hasil belajar Dasar Instalasi Listrik peserta didik yang diajarkan dengan strategi pembelajaran kontekstual.

$\mu_{A 2}=$ Rata-rata hasil belajar Dasar Instalasi Listrik peserta didik yang diajarkan dengan strategi pembelajaran ekspositori

$\mu_{B I} \quad=$ Rata-rata hasil belajar Dasar Instalasi Listrik peserta didik yang memiliki minat kejuruan tinggi.

$\mu_{B 2}=$ Rata-rata hasil belajar Dasar Instalasi Listrik peserta didik yang memiliki minat kejuruan rendah.

$A \times B=$ Interaksi antara strategi pembelajaran dan minat kejuruan dalam mempengaruhi hasil belajar Dasar Instalasi Listrik peserta didik.

\section{HASIL DAN PEMBAHASAN \\ Hasil}

Tabel 2. Rangkuman Data Hasil Perhitungan Analisis Deskriptif.

\begin{tabular}{|c|c|c|c|c|}
\hline \multirow{2}{*}{\multicolumn{2}{|c|}{$\begin{array}{c}\text { RINGKASAN } \\
\text { DATA }\end{array}$}} & \multicolumn{2}{|c|}{ STRATEGI PEMBELAJARAN } & \multirow[b]{2}{*}{ JUMLAH } \\
\hline & & Kontekstual & Ekspositori & \\
\hline \multirow{2}{*}{$\begin{array}{c}\text { MINAT } \\
\text { KEJURUAN }\end{array}$} & Tinggi & $\begin{array}{l}\mathrm{N}_{1}=18 \\
\Sigma X_{X}=621 \\
\Sigma X^{2}=21581 \\
\bar{X}_{1}=34.5 \\
\mathrm{SD}^{2}=6.55\end{array}$ & $\mid \begin{array}{l}N_{3}=19 \\
\Sigma X=498 \\
\Sigma X=13164 \\
\bar{X}_{3}=26.21 \\
\mathrm{SD}^{2}=3.96\end{array}$ & $\begin{array}{l}\mathrm{Nt}=37 \\
\Sigma \mathrm{X}=1119 \\
\Sigma \mathrm{X}^{2}=34745 \\
\bar{X}=30.36 \\
\mathrm{SD}^{2}=5.26\end{array}$ \\
\hline & Rendah & $\mid \begin{array}{l}\mathrm{N}_{2}=22 \\
\Sigma_{X}=651 \\
\Sigma X^{2}=19555 \\
\bar{X}=29.59\end{array}$ & \begin{tabular}{|l}
$\mathrm{N}_{4}=21$ \\
$\Sigma X=571$ \\
$\Sigma X^{2}=15701$ \\
$\bar{X}=27.19$
\end{tabular} & \begin{tabular}{|l}
$\mathrm{Nt}=43$ \\
$\Sigma X=1222$ \\
$\Sigma X^{2}=35256$ \\
$\bar{X}=28.39$
\end{tabular} \\
\hline
\end{tabular}




\begin{tabular}{|c|c|c|c|}
\hline & $\mathrm{SD}^{2}=7.9$ & $\mathrm{SD}^{2}=5.81$ & $\mathrm{SD}^{2}=6.86$ \\
\hline JUMLAH & $\begin{array}{l}\mathrm{Nt}=40 \\
\Sigma X=1272 \\
\Sigma X^{2}=41136 \\
\bar{X}=32.05 \\
\mathrm{SD}^{2}=7.23\end{array}$ & \begin{tabular}{||l}
$\mathrm{Nt}=40$ \\
$\Sigma X=1069$ \\
$\Sigma X^{2}=28865$ \\
$\bar{X}=26.7$ \\
$\mathrm{SD}^{2}=4.89$
\end{tabular} & $\begin{array}{l}\mathrm{Nt}=80 \\
\Sigma X=2341 \\
\Sigma X^{2}=70001 \\
\bar{X}=29.38 \\
\mathrm{SD}^{2}=6.06\end{array}$ \\
\hline
\end{tabular}

Untuk keperluan pengujian hipotesis dengan menggunakan teknik analisis varians dua jalur (ANAVA) faktorial 2 × 2 dan uji lanjut Scheffe diperlukan harga rata-rata tiap kelompok. Rangkuman data hasil belajar Dasar Instalasi Listrik dapat dilihat pada Tabel 2 dengan menggunakan analisis deskriptif. Setelah data Tabel 2 diolah dengan Anava 2 jalur faktorial 2x2, maka diperoleh hasil analisis seperti ditunjukkan pada Tabel 3.

Tabel 3. Ringkasan Hasil Perhitungan ANAVA Faktorial 2x2

\begin{tabular}{|c|c|c|c|c|c|c|}
\hline Sumber varians & JK & $\mathrm{Db}$ & RJK & Fh & $\begin{array}{c}\mathrm{Ft} \\
(\alpha=0.05)\end{array}$ & Ket \\
\hline Strategi Pembelajaran & 515.12 & 1 & 515.12 & 53.33 & \multirow[t]{6}{*}{3.96} & Signifikan \\
\hline Minat kejuruan & 66.21 & 1 & 66.21 & 6.85 & & Signifikan \\
\hline Interaksi & 181.94 & 1 & 181.94 & 18.83 & & Signifikan \\
\hline Antar Kelompok & 763.27 & & & & & \\
\hline Dalam Kelompok & 734.22 & 76 & 9.66 & & & \\
\hline Total & 2260.76 & 79 & & & & \\
\hline
\end{tabular}

Perbedaan Hasil Belajar Dasar Instalasi Listrik Peserta Didik yang Diajar dengan Strategi Pembelajaran Kontekstual Lebih Tinggi dengan Peserta Didik yang Diajar dengan Strategi Pembelajaran Ekspositori

$$
\begin{aligned}
& \text { Ho }: \mu_{\mathrm{A} 1}=\mu_{\mathrm{A} 2} \\
& \text { Ha }: \mu_{\mathrm{A} 1} \neq \mu_{\mathrm{A} 2}
\end{aligned}
$$

Hasil perhitungan analisis varians tentang rata-rata hasil belajar Dasar Instalasi Listrik peserta didik yang diajar dengan strategi pembelajaran kontekstual sebesar $\bar{X}=31.80$ dan rata-rata hasil belajar peserta didik yang diajar dengan strategi pembelajaran ekspositori $\bar{X}=26.73$, didapat hasil perhitungan $\mathrm{F}_{\mathrm{h}}$ sebesar 53.33 dan harga $F_{t}$ untuk taraf signifikansi $\alpha=0.05$ dengan derajat kebebasan $\mathrm{d}_{\mathrm{k}(1: 76)}$ adalah 3.96. Didapat $\mathrm{F}_{\mathrm{h}}$ (53.33) $>\mathrm{F}_{\mathrm{t}}$ (3.96), dengan demikian temuan penelitian menyimpulkan, bahwa Ho ditolak dan $\mathrm{Ha}$ diterima. Hipotesis penelitian yang menyatakan: Hasil belajar Dasar Instalasi Listrik peserta didik yang diajar dengan menggunakan strategi pembelajaran kontekstual lebih tinggi dibandingkan dengan peserta didik yang diajar dengan menggunakan strategi pembelajaran ekspositori pada taraf signifikansi $\alpha \square=0,05$ telah teruji kebenarannya.

Perbedaan Hasil Belajar Dasar Instalasi Listrik Peserta Didik yang Memiliki Minat Kejuruan Tinggi dengan Hasil Belajar Peserta Didik yang Memiliki Minat Kejuruan rendah.

$$
\begin{aligned}
& \text { Ho }: \mu_{\mathrm{B} 1}=\mu_{\mathrm{B} 2} \\
& \text { Ha }: \mu_{\mathrm{B} 1} \neq \mu_{\mathrm{B} 2}
\end{aligned}
$$

Hasil perhitungan analisis varians tentang rata-rata hasil belajar Dasar Instalasi Listrik peserta didik yang memiliki minat kejuruan tinggi sebesar $\bar{X}=30.24$ dan ratarata hasil belajar Dasar Instalasi Listrik peserta didik yang memiliki minat kejuruan rendah $\bar{X}$ $=28.42$. didapat hasil perhitungan $F_{h}$ sebesar 6.85 dan harga $F_{t}$ untuk taraf signifikansi $\alpha=$ 0.05 dengan derajat kebebasan $\mathrm{d}_{\mathrm{k}(1: 76)}$ adalah 3,96. Didapat $F_{h}$ (6.85) $>F_{t}$ (3.96), dengan demikian temuan penelitian menyimpulkan, bahwa Ho ditolak dan Ha diterima. Hipotesis penelitian yang menyatakan: Hasil belajar Dasar Instalasi Listrik peserta didik yang memiliki minat kejuruan tinggi lebih tinggi dibandingkan dengan peserta didik yang memiliki minat kejuruan rendah pada taraf signifikansi $\alpha=0,05$ telah teruji kebenarannya. 
Terdapat Interaksi antara Strategi Pembelajaran dengan Minat Kejuruan dalam Mempengaruhi Hasil Belajar Dasar Instalasi Listrik Peserta Didik.

Ho : $\mathrm{A} \times \mathrm{B}=0$

$\mathrm{Ha}: \mathrm{A} \times \mathrm{B} \neq 0$

Hasil perhitungan analisis varians tentang rata-rata hasil belajar Dasar Instalasi Listrik peserta didik untuk setiap kelompok perlakuan adalah sebagai berikut: Rata-rata hasil belajar Dasar Instalasi Listrik peserta didik yang diajar dengan strategi pembelajaran kontekstual dan memiliki minat kejuruan tinggi $\bar{X}=34.5$ dan hasil belajar Dasar Instalasi Listrik peserta didik yang diajar dengan strategi pembelajaran kontekstual dan memiliki minat kejuruan rendah $\bar{X}=29.59$ sedangkan hasil belajar Dasar Instalasi Listrik peserta didik yang diajar dengan strategi pembelajaran ekspositori dan memiliki minat kejuruan tinggi $\bar{X}=26.21$ dan hasil belajar Dasar Instalasi Listrik peserta didik yang diajar dengan strategi pembelajaran ekspositori dan memiliki minat kejuruan rendah $\bar{X}=27.19$. Hasil perhitungan ANAVA faktorial $2 \times 2$ diperoleh hasil perhitungan $F_{h}=18.83$ dan harga $F_{t}$ untuk taraf signifikansi $\alpha=0.05$ dengan $\mathrm{dk}=(1: 76)$ adalah 3,96. Didapat $\mathrm{F}_{\mathrm{h}}$ $(18.83)>F_{t}(3,96)$, dengan demikian temuan penelitian menyimpulkan, bahwa Ho ditolak dan Ha diterima. Hipotesis penelitian yang menyatakan: Terdapat interaksi antara strategi pembelajaran dengan minat kejuruan dalam mempengaruhi hasil belajar Dasar Instalasi Listrik peserta didik telah teruji kebenarannya pada taraf signifikansi 0.05 . Interaksi antara strategi pembelajaran dengan minat kejuruan dalam mempengaruhi hasil belajar Dasar Instalasi Listrik peserta didik dapat divisualisasikan secara grafis pada gambar 1 .

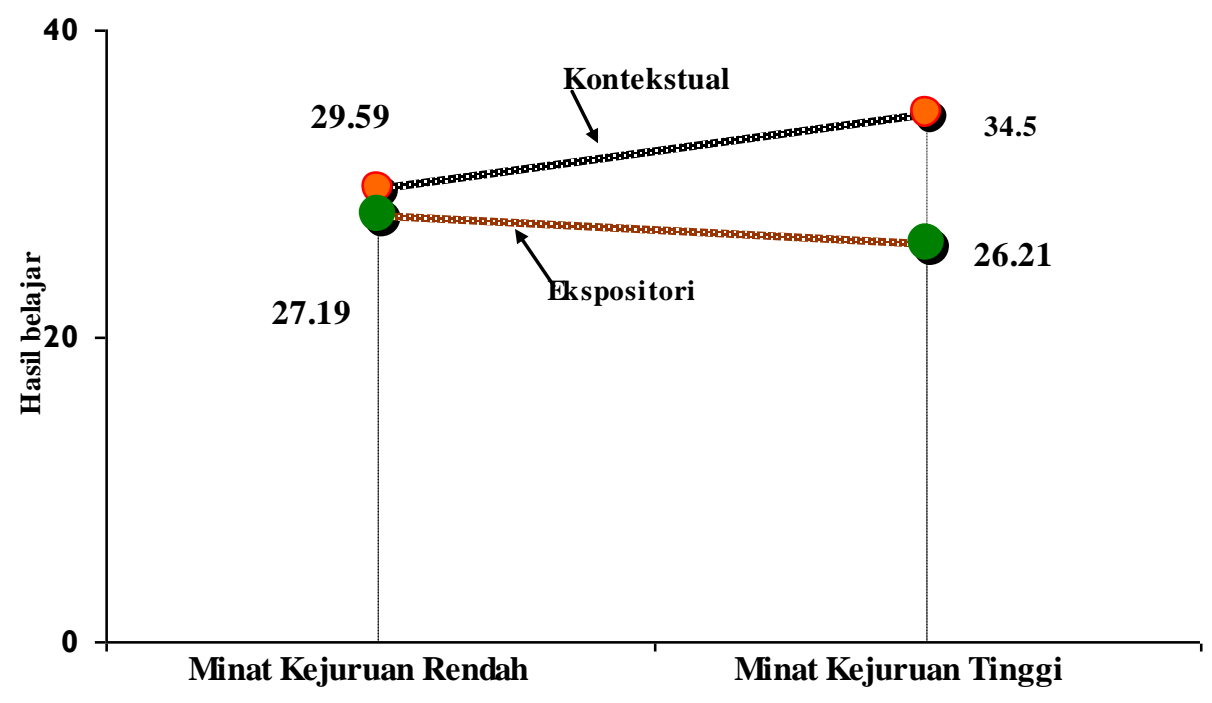

Gambar 1. Interaksi antara Strategi Pembelajaran dengan Minat Kejuruan dalam Mempengaruhi Hasil Belajar Dasar Instalasi Listrik Peserta Didik.

Berdasarkan hasil pengujian hipotesis ketiga yang menyatakan terdapat interaksi antara strategi pembelajaran dengan minat kejuruan dalam mempengaruhi hasil belajar Dasar Instalasi Listrik peserta didik, maka perlu dilakukan uji perbedaan rata rata antara dua proposisi untuk itu digunakan Uji Lanjut Scheffe. Gambar 1, menunjukkan terdapat interaksi antara strategi pembelajaran dengan minat kejuruan dalam mempengaruhi hasil belajar Dasar Instalasi Listrik peserta didik, akan tetapi strategi pembelajaran kontekstual lebih dominan dibandingkan dengan strategi pembelajaran ekspositori. Dengan kata lain semakin baik strategi pembelajaran yang digunakan oleh guru dalam menyampaikan bahan ajar, maka semakin tinggi pencapaian hasil belajar Dasar Instalasi Listrik peserta didik. Dilain pihak faktor minat kejuruan perlu diperhatikan karena terbukti bahwa minat kejuruan berpengaruh terhadap hasil belajar Dasar Instalasi Listrik peserta didik. Hasil 
pengujian dengan menggunakan Uji Scheffe dapat dilihat dalam Tabel 4.

Tabel 4. Ringkasan Hasil Pengujian dengan Menggunakan Uji Scheffe

\begin{tabular}{|c|c|c|c|}
\hline \multirow{2}{*}{ No } & \multirow{2}{*}{ Kelompok } & \multicolumn{2}{|c|}{ Uji Scheffe } \\
\hline & & $\mathrm{Fh}$ & $\mathrm{Ft}=0.05$ \\
\hline 1 & A1 dengan A2 & $7.698 *$ & 2.72 \\
\hline 2 & B1 dengan B2 & $2.835^{*}$ & \\
\hline 3 & $\mathrm{~A} 1 \mathrm{~B} 1$ dengan $\mathrm{A} 2 \mathrm{~B} 1$ & $8.080 *$ & \\
\hline 4 & A1B1 dengan A2B2 & $7.295^{*}$ & \\
\hline 5 & A1B1dengan A1B2 & $4.970 *$ & \\
\hline 6 & A1B2 dengan A2B1 & $3.474 *$ & \\
\hline 7 & $\mathrm{~A} 1 \mathrm{~B} 2$ dengan $\mathrm{A} 2 \mathrm{~B} 2$ & $2.532 \mathrm{ts}$ & \\
\hline 8 & $\mathrm{~A} 2 \mathrm{~B} 1$ dengan $\mathrm{A} 2 \mathrm{~B} 2$ & $0.992 \mathrm{ts}$ & \\
\hline
\end{tabular}

\section{Pembahasan}

Hasil penelitian menunjukkan bahwa hasil belajar Dasar Instalasi Listrik peserta didik yang diajar dengan strategi pembelajaran kontekstual lebih tinggi dibandingkan dengan peserta didik yang diajar dengan strategi pembelajaran ekspositori, dimana nilai rata-rata hasil belajar Dasar Instalasi Listrik peserta didik yang diajar dengan strategi pembelajaran kontekstual lebih tinggi dibandingkan nilai rata-rata hasil belajar peserta didik yang diajar dengan strategi pembelajaran ekspositori. Hal ini juga ditunjukkan hasil perhitungan Uji Scheffe. Hal ini berindikasi bahwa strategi pembelajaran kontekstual lebih baik dalam meningkatkan pemahaman peserta didik tentang Dasar Instalasi Listrik dibandingkan dengan strategi pembelajaran ekspositori. Hasil ini menunjukkan bahwa untuk mengajarkan materi pelajaran Dasar Instalasi Listrik lebih baik menggunakan strategi pembelajaran kontekstual dibandingkan dengan strategi ekspositori.

Sukamto (2006) meneliti tentang pengaruh strategi pengorganisasian pembelajaran dan kemandirian mahapeserta didik terhadap prestasi belajar Pengembangan Kurikulum Fakultas Tarbiyah IAIN Sumut, menunjukkan bahwa prestasi belajar Pengembangan Kurikulum mahapeserta didik semester V (lima) Fakultas Tarbiyah IAIN yang diajar dengan strategi pengorganisasian pembelajaran kontekstual lebih baik dibandingkan dengan jika diajar menggunakan strategi pengorganisasian pembelajaran model buku teks.

Hasil penelitian menunjukkan bahwa hasil belajar Dasar Instalasi Listrik peserta didik yang memiliki minat kejuruan tinggi lebih tinggi dibandingkan peserta didik yang memiliki minat kejuruan rendah, dimana nilai rata-rata hasil belajar Dasar Instalasi Listrik peserta didik yang memiliki minat kejuruan tinggi lebih tinggi dibandingkan peserta didik yang memiliki minat kejuruan rendah.

Hasil penelitian menunjukkan bahwa hasil belajar Dasar Instalasi Listrik peserta didik yang memiliki minat kejuruan tinggi lebih tinggi dibandingkan peserta didik yang memiliki minat kejuruan rendah jika diajar dengan strategi pembelajaran kontekstual dimana nilai rata-rata hasil belajar Dasar Instalasi Listrik peserta didik yang memiliki minat kejuruan tinggi lebih tinggi dibandingkan peserta didik yang memiliki minat kejuruan rendah jika diajar dengan strategi pembelajaran kontekstual. Tetapi sebaliknya nilai rata-rata hasil belajar Dasar Instalasi Listrik peserta didik yang memiliki minat kejuruan tinggi lebih rendah dibandingkan peserta didik yang memiliki minat kejuruan rendah jika diajar dengan strategi pembelajaran ekspositori. Hal ini berindikasi bahwa peserta didik yang memiliki minat kejuruan tinggi lebih mampu memahami secara mendalam terhadap tugas dan materi Dasar Instalasi Listrik diajar dengan strategi pembelajaran kontekstual.

Minat kejuruan sebagai salah faktor kognitif merupakan karakteristik yang turut mempengaruhi efektivitas proses belajar. Secara teoritis peserta didik SMA Negeri 2 Pematangsiantar telah berada pada tahap operasi formal, yang mana peserta didik pada tahap ini telah dapat menggunakan operasi 
konkritnya untuk membentuk operasi yang lebih kompleks. Minat kejuruan dapat digunakan untuk mengidentifikasi dan mengklasifikasi rangsangan atau pengaruh berbeda dari luar sehingga peserta didik dapat dengan cepat dapat beradaptasi menyesuaikan apa yang diketahui dengan apa yang akan dipelajarinya. Minat kejuruan berpengaruh terhadap kemampuan peserta didik dalam menyelesaikan masalah atau soal-soal Dasar Instalasi Listrik. Didalam ranah kognitif, belajar Dasar Instalasi Listrik membutuhkan minat kejuruan tinggi guna menyelesaikan masalahmasalah dari gejala-gejala yang nyata hingga yang abstrak.

Peserta didik yang memiliki minat kejuruan yang tinggi cenderung dapat menyelesaikan persoalannya sendiri tanpa mendapat hambatan yang berarti dan cenderung lebih memilih untuk belajar secara mandiri untuk memecahkan persoalannya sendiri. Peserta didik yang memiliki minat kejuruan rendah cenderung untuk menyukai cara belajar dan memecahkan persoalannya dengan bantuan orang lain. Peserta didik yang memiliki minat kejuruan rendah lebih menyukai cara belajar berkelompok untuk memecahkan persoalan secara bersama-sama.

Temuan penelitian menunjukkan bahwa terdapat interaksi antara strategi pembelajaran dengan minat kejuruan dalam mempengaruhi hasil belajar Dasar Instalasi Listrik peserta didik. Hasil belajar Dasar Instalasi Listrik peserta didik yang diajar dengan strategi pembelajaran kontekstual dan memiliki minat kejuruan tinggi lebih tinggi dibandingkan dengan peserta didik yang memiliki minat kejuruan rendah. Sedangkan hasil belajar Dasar Instalasi Listrik peserta didik yang diajar dengan strategi pembelajaran ekspositori dan memiliki minat kejuruan rendah lebih tinggi dibandingkan dengan peserta didik yang memiliki minat kejuruan tinggi. Hal ini memberikan pemahaman bahwa peserta didik yang memiliki minat kejuruan tinggi lebih baik diajar dengan strategi pembelajaran kontekstual sedangkan peserta didik yang memiliki minat kejuruan rendah lebih baik diajar dengan strategi pembelajaran ekspositori.

Strategi pengorganisasian pembelajaran secara kontekstual, salah satu jenis strategi pembelajaran yang memiliki ciri khas penyajian dari hal-hal yang umum ke hal-hal yang rinci. Komponen strategi ini meliputi; urutan kontekstual yaitu urutan materi dari sederhana ke kompleks atau dari urutan umum-ke-rinci, epitome atau kerangka isi yang berfungsi sebagai konteks atau kerangka dari isi bidang studi yang lebih rinci, rangkuman yang memuat bagian isi bidang studi yang penting, biasanya berupa pengertian singkat dari konsep, prosedur atau prinsip yang dipelajari, dan pensintesis, yang berfungsi untuk menunjukkan keterkaitan diantara konsep, prosedur, atau prinsip yang telah diajarkan. Artinya pensintesis tersebut diberikan dengan tujuan untuk memudahkan pemahaman, peningkatan motivasi, dan meningkatkan retensi peserta didik dalam belajar.

Karakteristik strategi pembelajaran secara ekpositori adalah dilakukan oleh guru dengan cara menyampaikan materi pelajaran secara verbal, artinya bertutur secara lisan merupakan alat utamanya karena itu sering diidentikan dengan ceramah, biasanya materi pelajaran yang disampaikan adalah materi pelajaran yang sudah jadi, seperti data atau fakta konsep-konsep tertentu yang harus dihafal sehingga tidak menuntut peserta didik untuk berpikir ulang, tujuan utama pembelajaran adalah penguasaan materi pelajaran itu sendiri. Artinya, setelah proses pembelajaran berakhir peserta didik diharapkan dapat memahaminya dengan benar dengan cara dapat mengungkapkan kembali materi yang telah diuraikan. Strategi pembelajaran ekspositori merupakan bentuk dari pendekatan pembelajaran yang berorientasi kepada guru.

Berdasarkan penjelasan di atas, dapat disimpulkan bahwa terdapat keterkaitan pada proses pembelajaran secara keseluruhan yang dilakukan oleh seorang guru dalam pencapaian hasil belajar yang lebih tinggi. Strategi pembelajaran yang berbeda memberi pengaruh yang berbeda terhadap hasil belajar peserta didik dikaitkan dengan motivasi berprestasi yang dimilikinya.

Peserta didik yang memiliki minat kejuruan yang tinggi cenderung dapat menyelesaikan persoalannya sendiri tanpa mendapat hambatan yang berarti dan cenderung lebih memilih untuk belajar secara mandiri untuk memecahkan persoalannya sendiri sedangkan peserta didik yang memiliki minat kejuruan rendah cenderung untuk menyukai cara belajar dan memecahkan persoalannya dengan bantuan orang lain. Peserta didik yang memiliki minat kejuruan rendah lebih menyukai cara belajar berkelompok untuk memecahkan persoalan secara bersama-sama. 
Peserta didik yang memiliki kamampuan berpikir logis tinggi apabila diberi perlakuan dengan strategi pembelajaran kontekstual akan memperoleh hasil belajar lebih tinggi dibandingkan dengan menggunakan strategi pembelajaran ekspositori, sebab peserta didik yang memiliki kamampuan berpikir logis tinggi mampu menemukan sendiri pengetahuan dan keterampilan yang dibutuhkannya dengan cara mengaitkan antara pengetahuan dan keterampilan dasar yang telah dimiliki dengan pengetahuan dan keterampilan baru yang dibutuhkannya. Peserta didik dengan minat kejuruan tinggi jika dibelajarkan dengan strategi pembelajaran kontekstual akan mampu berpikir secara logis dan rasional dalam menyelesaikan soal-soal secara rinci, terurut, dan menggunakan langkah-langkah penyelesaian soal secara sistematis, karena mampu mengaitkan antara materi yang sudah dikuasai dengan materi yang akan dipelajari olehnya.

Untuk peserta didik yang memiliki minat kejuruan rendah jika diajar dengan strategi pembelajaran ekspositori akan memperoleh hasil belajar Dasar Instalasi Listrik yang lebih tinggi dibandingkan jika diajar strategi pembelajaran kontekstual. Peserta didik dengan minat kejuruan rendah jika diajar dengan strategi pembelajaran kontekstual akan mengalami kesulitan untuk membangun atau mengkonstruk pengetahuan yang dibutuhkannya, sebab peserta didik dengan minat kejuruan rendah memiliki tingkat kecepatan yang rendah dalam menyelesaikan soal-soal Dasar Instalasi Listrik. Pembelajaran kontekstual menuntut kemampuan dalam menyelesajkan soal-soal secara rinci, terurut, dan sistematis

Berdasarkan penjelasan di atas, dapat disimpulkan bahwa terdapat keterkaitan pada proses pembelajaran secara keseluruhan yang dilakukan oleh seorang guru dalam pencapaian hasil belajar yang lebih tinggi. Strategi pembelajaran yang berbeda memberi pengaruh yang berbeda terhadap hasil belajar peserta didik dikaitkan dengan minat kejuruan yang dimilikinya.

\section{PENUTUP}

Berdasarkan hasil pengujian hipotesis seperti yang telah diuraikan, penelitian ini menyimpulkan bahwa:

1. Hasil belajar Dasar Instalasi Listrik peserta didik yang diajar dengan strategi pembelajaran kontekstual lebih tinggi dibandingkan hasil belajar peserta didik yang diajar dengan strategi pembelajaran ekspositori.

2. Hasil belajar Dasar Instalasi Listrik peserta didik yang memiliki minat kejuruan tinggi lebih tinggi dibandingkan dengan peserta didik yang memiliki minat kejuruan rendah.

3. Terdapat interaksi antara strategi pembelajaran dengan minat kejuruan dalam mempengaruhi hasil belajar Dasar Instalasi Listrik peserta didik. Hasil belajar Dasar Instalasi Listrik peserta didik yang diajar dengan strategi pembelajaran kontekstual dan memiliki minat kejuruan tinggi lebih tinggi dibandingkan dengan peserta didik yang memiliki minat kejuruan rendah. Sedangkan hasil belajar Dasar Instalasi Listrik peserta didik yang diajar dengan strategi pembelajaran ekspositori dan memiliki minat kejuruan rendah lebih tinggi dibandingkan dengan peserta didik yang memiliki minat kejuruan tinggi. Dengan demikian, peserta didik yang memiliki minat kejuruan tinggi lebih baik diajar dengan strategi pembelajaran kontekstual sedangkan peserta didik yang memiliki minat kejuruan rendah lebih baik diajar dengan strategi pembelajaran ekspositori.

\section{DAFTAR PUSTAKA}

Arikunto, S, (2001), Dasar-Dasar Evaluasi Pendidikan, Bumi Aksara, Jakarta.

Arikunto, S, (2005), Manajemen Penelitian, Rineka Cipta, Jakarta.

Atmadi, A dan Y. Setyaningsih. 2000. Transformasi Pendidikan Memasuki

Millenium Ketiga. Yogyakarta: Kanisius

Bigge, Morris L. 1982. Learning Theories For Teachers. New York: Harper \& Row

Buchari, Mochtar. (2001). Pendidikan Antisipatoris. Yogyakarta: Kanisius.

Dick, W \& Carey, L. (2005). The Systematic Design of Instrustional. New York: Longman

Dimyati dan Mudjono. (2006). Belajar dan Pembelajaran. Jakarta: Rineka Cipta

Fajar, Arnie. (2004). Portofolio dalam pembelajaran IPS. Bandung: PT. Remaja Rosdakarya

Furchan, Arief, (2005), Pengantar Penelitian Dalam Pendidikan, Pustaka Pelajar, Yogyakarta. 
Gagne, Robert M \& Driscoll, Marcy P. 1989. Essentials of Learning for Instruction. New Jersey: Prentice Hall

Gerlach, Vernon S \& Ely, Donald P. (1980). Teaching \& Media, A Systematic Approach. New Jersey: Prentice Hall

Jarolimek, John \& Foster, Clifford D. (1976). Teaching and Learning in the Elementary School. London: Macmillan

Jhonson, Elaine, B, (2007), Contextual Teaching \& Learning, MLC, Bandung.

Miarso, Yusufhadi. (2007). Menyemai Benih Teknologi Pendidikan. Jakarta: Kencana

Mulich, M, (2007), KTSP Pembelajaran Berbasis Kompetensi dan Kontekstual, Bumi Aksara, Jakarta

Mulyasa, E, (2004), Implementasi Kurikulum 2004, Remaja Rodakarya, Bandung.

Nurhadi, (2003), Pembelajaran Kontekstual dan Penerapannya Dalam KBK, Universitas Negeri Malang, Malang.

Nurhadi, (2004), Kurikulum 2004, Gramedia Widiasarana, Jakarta.
Prawiradilaga, Dewi Salma. (2008). Prinsip Disain Pembelajaran. Jakarta: Kencana

Romizwoski, A.J. (1981). Instructional Design System, Decision Making in Course Planning and Curriculum Design. London: Kogan

Sagala, Syaiful, H, (2003), Konsep dan Makna Pembelajaran, Alfabeta, Bandung.

Sanjaya, W, (2005), Pembelajaran Dalam Implementasi Kurikulum Berbasis Kompetensi, Kencana Prenada, Jakarta.

Slameto, (2003), Belajar dan Faktor-Faktor Yang Mempengaruhinya, Rineka Cipta, Jakarta.

Sudjana, (2005), Metode Statistik, Tarsito, Bandung.

Suparman, M. Atwi. (2001). Desain Instruksional. Jakarta: PAU-PPAI Universitas Terbuka

Syah, Muhibbin.(2008). Psikologi Belajar. Jakarta: RajaGrafindo Persada 